\title{
When and Which Companies Are Better Suited to Use Factoring
}

\author{
Shpresa Çela ${ }^{1}$ \\ ${ }^{1}$ Faculty of Economics, University of Tirana, Albania \\ Correspondence: Shpresa Çela, Ph.D, Prof. External Finance Department, FEUT, Head of Finance at CELA Sh.p.k, \\ Albania. Tel: 355-68-209-5870.
}

Received: February 25, 2016

Accepted: March 12, 2016

Online Published: March 30, 2016

doi:10.5430/rwe.v7n1p35

URL: http://dx.doi.org/10.5430/rwe.v7n1p35

\begin{abstract}
A healthy cash flow is a very important point for a business. Many facts show that a healthy cash flow is more important even than the creation or distribution of goods and services. Being one of the key points, the cash flow is defined as a management tool in the company. So the management continuously requires different financing ways for the company in order to significantly decrease the gap created between the liquidation of payable accounts period and collection of receivable accounts. In the world there are diverse financing ways, by which the most common are bank loans. But with the trade development is also increasingly developing the factoring industry (Note 1). The purpose of this analysis is to sift through given examples the moment when a company needs factoring, to analyze the gap of liquidity and also, through an econometric model built on the basis of a empirical study, that we have done for 110 SMEs in Albania, to prove that the indicators of liquidity determine which companies are better suited to use factoring as a financing source for the working capital.
\end{abstract}

Keywords: realization of inventory supply, sale, cash in period, client receivables, cost of, econometric model

\section{When a Company Can Think about Factoring?}

1.1 When a Company Can Think about Factoring?

It is uncommon to hear "spend money to make money" because the concept of expenditure itself is related to the cost. Costs' rising forces a business to be excluded from the current market. Even more, the demand for money in business requires efforts and time. All arises when suppliers invoices are paid before the money generated from sales are made receivables. A business can be successful and have a large amount of sales but it can also fail from gap of money. (Note 2) At this moment the management should be extremely careful seeking that the suppliers liquidation to be as far away as possible, focusing the purchases on inventories that have a high turnover ratio and by making discounts for those clients that pay their bills very quickly. 


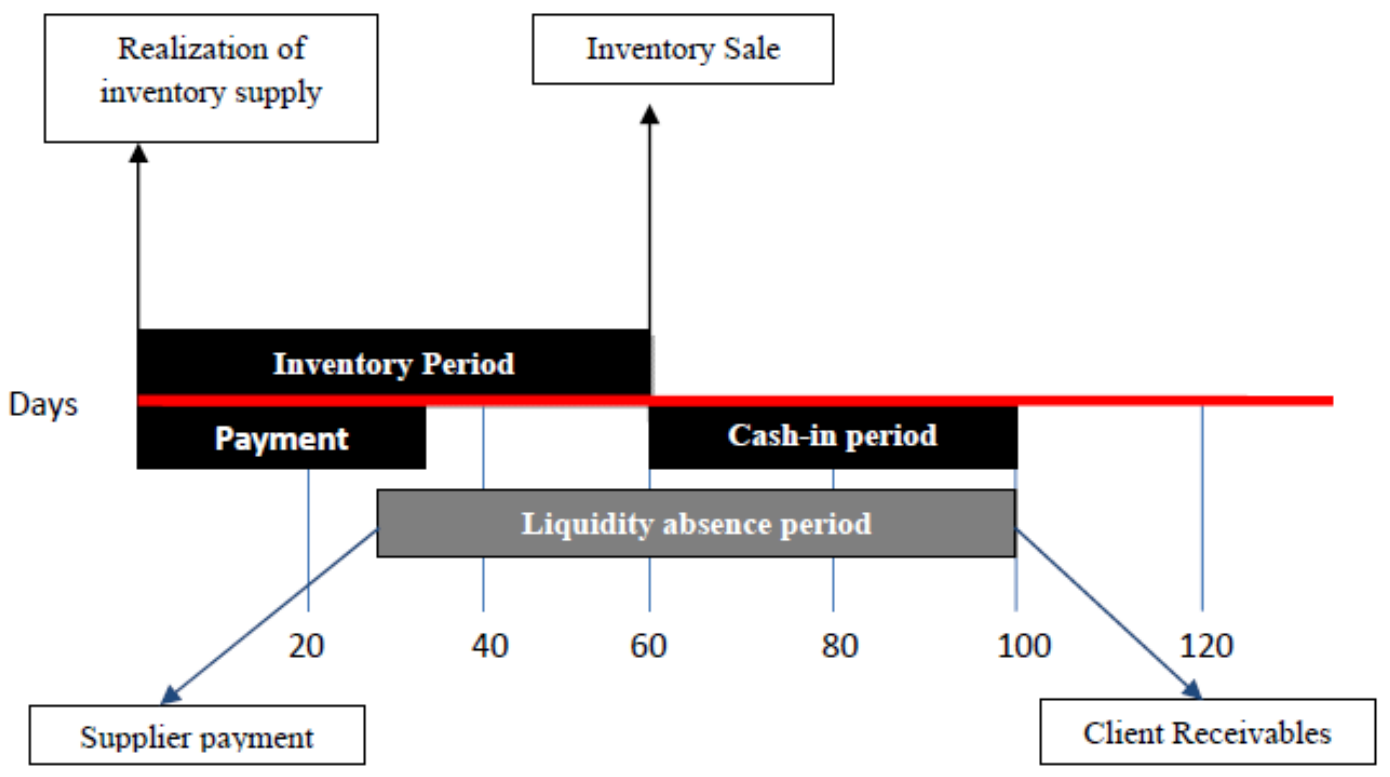

Figure 1. Gap of funds creation

As seen in Figure 1, the gap of funds is created exactly in the period between the moment of the supplier payment and the moment of client receivables. At this moment, the management should determine the company's movement. If the company is located in the gray zone, which corresponds with the creation of gap of liquidity, then the company should spend some extra money to continue to maintain its position in the market. This money it will spend either by taking loans, which will require more time, passing even the gray period of the company, or by financing with factoring. And in these moments the faster way is factoring but it is also more expensive. The extension of the gap of liquidity period increases the borrowing costs for businesses. To explain this, let us analyze an example.

The metal company has an average operating cost 10,000 Euros per day. The period between returning the inventory in cash is 100 days. In order to ensure the operation this company should have 1,000,000 Euros (10,000 Euros / day $\mathrm{X} 100$ days). If the company does not have these funds, it will be forced to borrow. Let's assume that the company will borrow at $10 \%$ interest rate. So the borrowing cost in this case would be 100,000 Euros (1,000,000 Euros

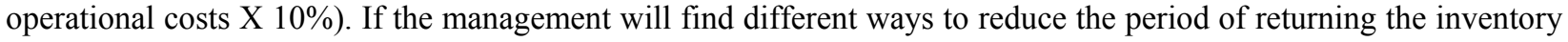
in cash, then the borrowing costs would be lower. So if the returning period of inventory in cash for this company will be reduced to 50 days, then the operating costs in order to cover up the gap of liquidity period would be reduced at 500,000 Euros (10,000 Euros X 50 days). This also brings as a result the reduction of borrowing costs to 50,000 Euros (500,000 Euros X 10\% interest rate).

Table 1. Gap of liquidity analysis

\begin{tabular}{lrrrr}
\hline $\begin{array}{l}\text { ABC Company } \\
\text { Gap of liquidity analysis }\end{array}$ & $€$ & $3,650,000$ & $€$ & $3,650,000$ \\
\hline Annual operational costs & $€$ & 10,000 & $€$ & 10,000 \\
\hline Daily operational costs ( 365 ) & & 100 & & 50 \\
\hline Average period of gap of liquidity (days) & $€$ & $1,000,000$ & $€$ & 500,000 \\
\hline Needed loan for operation & & $10 \%$ & & $10 \%$ \\
\hline Loan interest rate & $€$ & 100,000 & $€$ & 50,000 \\
\hline Financing cost & & & & \\
\hline
\end{tabular}


As seen from the example the reduction of the gap of liquidity period brings even the reduction of operational costs. But small companies, having limitations in technology, in the negotiations possibilities with the suppliers about the benefits of credit terms cannot do much in order to reduce this period. By having this kind of market position they face not a very positive cash flow situation. As a result they find factoring as a solution.

\section{Empirical Study}

\subsection{Empirical Study (Note 3)}

To realize the purpose of this research paper, we reckon the empirical analyzes conducted from many authors for American and British market (Note 4). They analyzed companies that use factoring in different point of view, based on the type of organization and type of financing. These authors suggested the importance of variables (size of company, age of company, structure of company growth of the company) and the relationship between these variables and the opportunity to use factoring as a financial source.

The empirical study has taken in consideration 110 companies. Only 26 from them use factoring as financial source. This empirical study will indicate how different variables (cash-flow, coherent ratio, loan, receivable accounts) influence the usage of factoring. We verified that liquidation indicators are important variables in usage of factoring as a financial source.

The empirical study is realized the hypothesis below:

H.1 The lower the level of the cash-flow more SMEs tend to use factoring.

H.2.The lower the current report is, the more SMEs tend to use factoring

H.3. The higher the level of debt, the lower is the possibility to take loans from banks and so higher the possibility of using factoring as a source of short-term financing of SMEs.

\section{Hypothesis 1: The lower the level of the cash-flow more SMEs tend to use factoring.}

Regression Analysis: Cash Flow versus factoring.

We are analyzing a specific liquidity which is cash flow. The lower the level of cash flow in the economy's unit the more this unit needs external financing, because with the money generated from the operating activities it cannot afford to pay all its short-term obligations. So we can say that the unit lacks liquidity. This situation could lead the unit to foreclosure of investment and its assets, but in the latest case it leads to bankruptcy and complete liquidation. The decrease of the level of cash-flow from operating activities was due to some problems which can be, fast sales growth, from the slow turnover of inventories but also by increased receivable accounts and also from the restriction of trade credit from suppliers. We thought that this is an important indicator that affects the use of factoring. For this reason, through multiple regression analysis we proved its importance. The data are taken from Table 2. Here below. 
Table 2

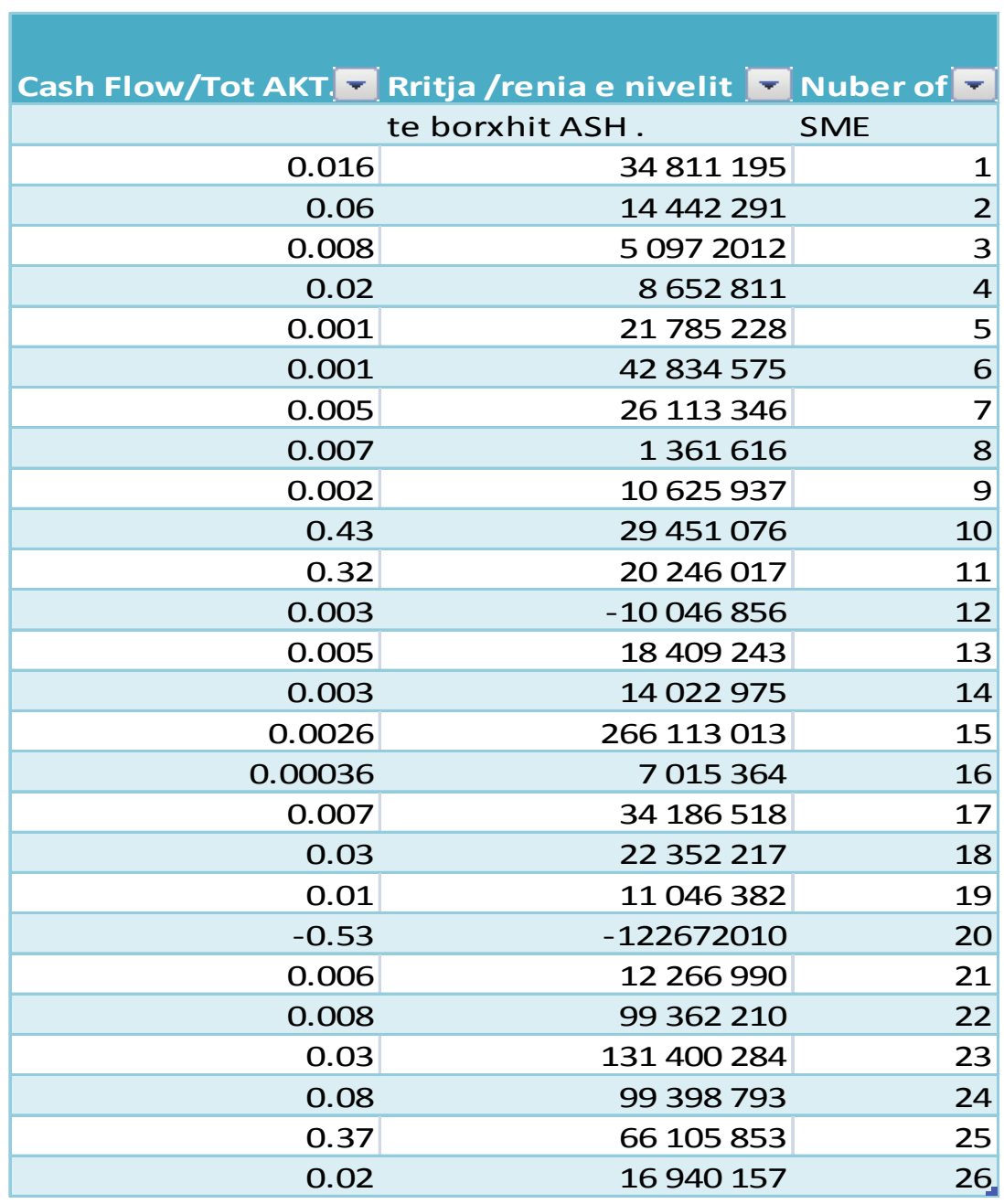

Source: Shpresa Çela

The equation of regression is: Factoring $=\mathbf{3 0 . 8 8 4}+\mathbf{1 3 5 . 7}$ Cash Flow

Table 3. Regression analysis: Statistical indicators

\begin{tabular}{lllll}
\hline Predictor & Coefficients & Standard Error & t Stat & P-value \\
\hline Intercept & $30,884,914$ & $12,487,006$ & 2 & 0 \\
\hline Cash Flow/Tot AKT. & $135,732,144$ & $75,121,141$ & 2 & 0 \\
\hline
\end{tabular}

Table 4. Regression analysis: Cash -flow toward factoring

\begin{tabular}{lc}
\hline \multicolumn{2}{c}{ Regression Statistics } \\
\cline { 2 - 3 } Multiple R & 0.3460 \\
\hline R Square & 0.1197 \\
\hline Adjusted R Square & 0.0831 \\
\hline Standard Error & $62,228,276$ \\
\hline Observations & 26 \\
\hline
\end{tabular}

$\mathrm{S}=62,228276 \quad \mathrm{R}-\mathrm{Sq}=23 \% \quad \mathrm{R}-\mathrm{Sq}(\operatorname{adj})=26 \%$ 
Table 5. Analysis of variance

\begin{tabular}{lllllll}
\hline \multicolumn{1}{c}{ Source } & df & \multicolumn{1}{c}{ SS } & MS & F & Significance $\mathbf{P}$ \\
\hline Regression & 1 & $12,642,023,809,506,300$ & $12,642,023,809,506,300$ & 3 & 0 \\
\hline Residual & 24 & $92,936,600,264,042,000$ & $3,872,358,344,335,080$ & & \\
\hline Total & 25 & $105,578,624,073,548,000$ & & & & \\
\hline
\end{tabular}

By analyzing the data of the above regression we see that even under this analysis the indicator of cash flow is very important in the use of factoring.

This clearly expressed by the probability that the value is $0<0.5$.

As it appears from the graph the decrease of factoring cash flow have a positive correlation.

This is clearly expresses from the first sign $\mathrm{X}$ which is positive. This means that the lower the level of cash flow, the higher is the use of factoring by SMEs.

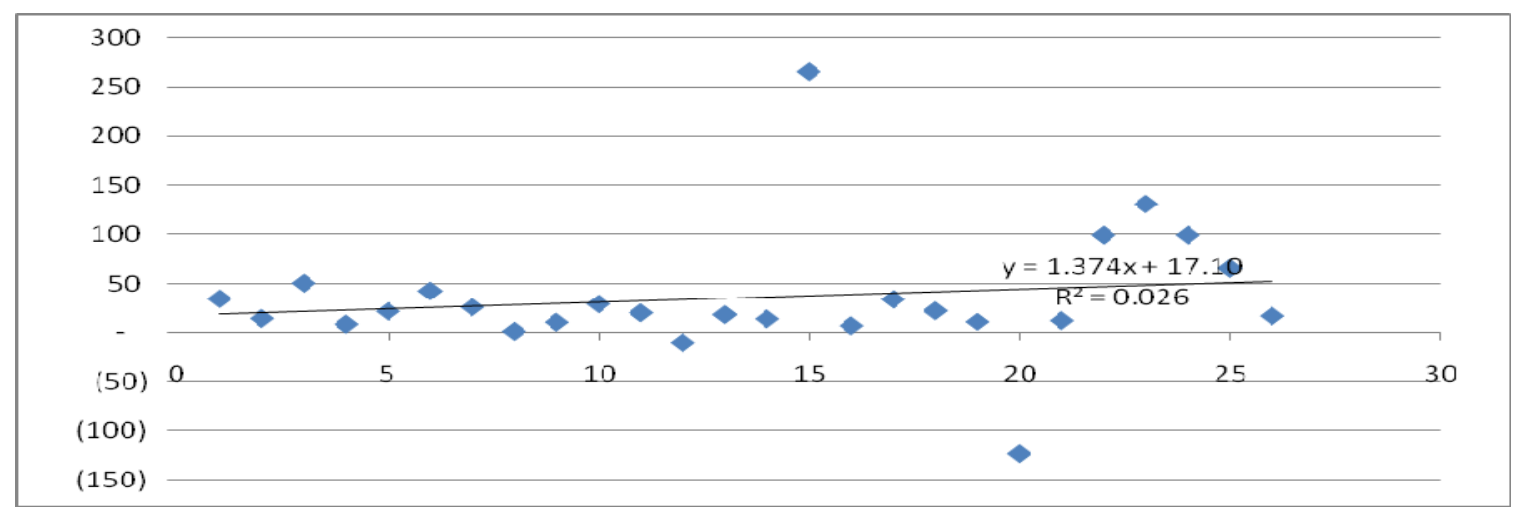

Figure 2. Correlation between cash flow and factoring

So thus we have proved the above hypothesis.

\section{Hypothesis 2: The lower the current report is, the more SMEs tend to use factoring.}

Current ratio versus factoring

Another indicator that we have defined as important is the current ratio. As it is known it is calculated from the relation between short-term assets / short-term liabilities. This ratio should be at least "2" which means that the company has "2" ALL (Lek) invested active in short-term assets for each "1" ALL (lek) short-term obligations. But here we will analyze, through multiple regressions, the importance of this indicator to the use the factoring.

For this reason we used the data of Table 6 in the paper for regression analysis.

Table 6

\begin{tabular}{|rrr} 
Coherent Ratio & $\begin{array}{r}\text { Increase/decrease of short } \\
\text { term liabilities }\end{array}$ & $\begin{array}{r}\text { Number } \\
\text { Of SME }\end{array}$ \\
\hline $\mathbf{0 . 9}$ & 34811195 & 1 \\
\hline $\mathbf{0 . 6}$ & 14442291 & 2 \\
\hline $\mathbf{0 . 6}$ & 50972012 & 3 \\
\hline $\mathbf{1 . 2}$ & 8652811 & 4 \\
\hline $\mathbf{0 . 8}$ & 21785228 & 5 \\
\hline $\mathbf{1 . 4}$ & 42834575 & 6 \\
\hline
\end{tabular}




\begin{tabular}{rrr}
\hline $\mathbf{0 . 9 6}$ & 26113346 & 7 \\
\hline $\mathbf{0 . 8 2}$ & 1361616 & 8 \\
\hline $\mathbf{0 . 8}$ & 10625937 & 9 \\
\hline $\mathbf{1 . 5}$ & 29451076 & 10 \\
\hline $\mathbf{1 . 5}$ & 20246017 & 11 \\
\hline $\mathbf{2}$ & -10046856 & 12 \\
\hline $\mathbf{1 . 5}$ & 18409243 & 13 \\
\hline $\mathbf{0 . 9}$ & 14022975 & 14 \\
\hline $\mathbf{0 . 9}$ & 266113013 & 15 \\
\hline $\mathbf{1 . 5}$ & 7015364 & 17 \\
\hline $\mathbf{0 . 9}$ & 34186518 & 18 \\
\hline $\mathbf{0 . 8}$ & 22352217 & 19 \\
\hline $\mathbf{1}$ & 11046382 & 20 \\
\hline $\mathbf{4 . 1}$ & -122672010 & 21 \\
\hline $\mathbf{1 . 9}$ & 12266990 & 22 \\
\hline $\mathbf{2 . 2}$ & 99362210 & 23 \\
\hline $\mathbf{1 . 3}$ & 131400284 & 24 \\
\hline $\mathbf{1 . 0 8}$ & 99398793 & 25 \\
\hline $\mathbf{1 . 4}$ & 66105853 & 26 \\
\hline $\mathbf{1 . 2}$ & 16940157 & \\
\hline & & \\
\hline & &
\end{tabular}

Source: Shpresa Çela

The regression equation is: Factoring $=84942-38530$ cleaner Report

For this reason we have used the data of Table 7 at the end of the study of regress analyses.

The equation of regression is: Factoring $=\mathbf{8 4 9 4 2}-\mathbf{3 8 5 3 0}$ current ratio

Table 7. Regression statistics

\begin{tabular}{lr}
\hline Multiple R & 0.413867 \\
\hline R Square & 0.171286 \\
\hline Adjusted R & \\
Square & 0.136757 \\
\hline Standard Error & 60378824 \\
\hline Observations & 26 \\
\hline
\end{tabular}

Table 8. Regression analysis: Statistical indicators

\begin{tabular}{ccccc}
\hline Predictor & Coefficients & Standard Error & t Stat & P-value \\
\hline Intercept & 84942650 & 25095950.28 & 3.38471544 & 0.0024478 \\
\hline $\begin{array}{c}\text { Current Report } \\
\text { Akt.Qark/Tot. Akt }\end{array}$ & -3.85307 & 17040711.81 & -2.2272277 & 0.03556882 \\
\hline $60378823.74 \quad \mathrm{R}-\mathrm{Sq}=24 \%$ & $\mathrm{R}-\mathrm{Sq}(\mathrm{adj})=28 \%$ & & &
\end{tabular}


Table 9. Analysis of variance

\begin{tabular}{lccccc}
\hline Source & df & SS & MS & F & Significance \\
\hline Regression & 1 & $1.80842 \mathrm{E}+16$ & $1.8084 \mathrm{E}+16$ & 4.96054307 & 0.035568816 \\
\hline Residual & 24 & $8.74945 \mathrm{E}+16$ & $3.6456 \mathrm{E}+15$ & & \\
\hline Total & 25 & $1.05579 \mathrm{E}+17$ & & & \\
\hline
\end{tabular}

Analyzing data regression results above current ratio an important indicator.

Value of $\mathrm{p}$ (probability) $0.035<0: 05$ which show the importance of the impact of the current report the use of factoring.

So through multiple regression analysis only confirmed the hypothesis that the less liquid or FIME be a much less have more current report is keen to use factoring as an option for external financing for working capital. This conclusion and said the following graph.

\section{Coherent ratio}

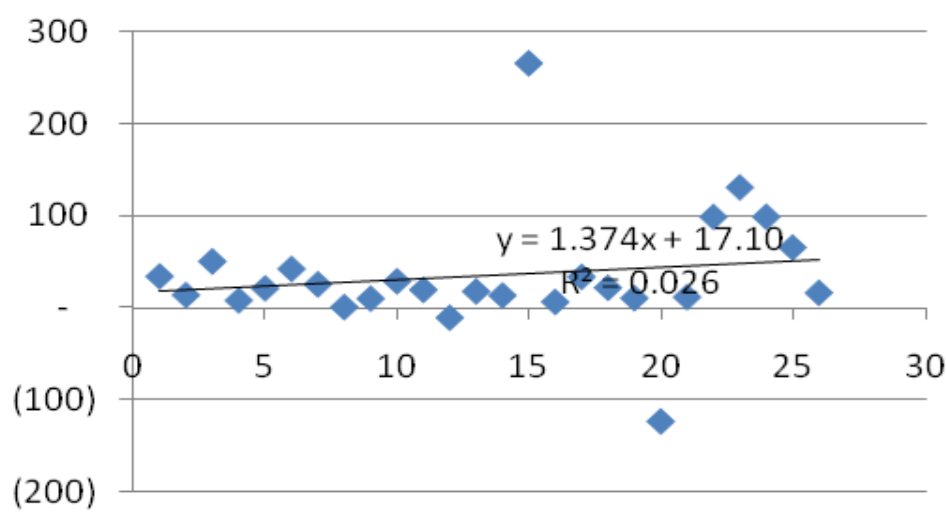

Figure 3. Relationship between current ratio and use of factoring

\section{Hypothesis 3: The higher the level of debt, the lower is the possibility to take loans from banks and so higher the possibility of using factoring as a source of short-term financing of SMEs.}

One of the economic indicators that we have selected as important and we think that can affect the use of factoring is the debt ratio.

This report takes into account all the assets financed with debt. A company with large amounts of debt, has difficulties in expanding debt financing because lenders can only lend to higher interest rates. The above is part of the debt; the greater is the degree of risk because in case of bankruptcy, creditors must be settled before the owners. For this reason we think that companies or SMEs which have high levels of debt tend to use factoring. For this reason we used the data of Table 10 below: 
Table 10

\begin{tabular}{|c|c|c|}
\hline Total liability/ total active & $\begin{array}{l}\text { Increase/decrease of short term } \\
\text { liabilities }\end{array}$ & $\begin{array}{l}\text { Number of } \\
\text { SME }\end{array}$ \\
\hline 0.99 & 34811195 & 1 \\
\hline 0.91 & 14442291 & 2 \\
\hline 0.99 & 50972012 & 3 \\
\hline 0.38 & 8652811 & 4 \\
\hline 0.3 & 21785228 & 5 \\
\hline 0.66 & 42834575 & 6 \\
\hline 0.26 & 26113346 & 7 \\
\hline 0.6 & 1361616 & 8 \\
\hline 0.95 & 10625937 & 9 \\
\hline 0.86 & 29451076 & 10 \\
\hline 0.68 & 20246017 & 11 \\
\hline 0.31 & -10046856 & 12 \\
\hline 0.75 & 18409243 & 13 \\
\hline 0.44 & 14022975 & 14 \\
\hline 0.8 & 266113013 & 15 \\
\hline 0.35 & 7015364 & 16 \\
\hline 0.78 & 34186518 & 17 \\
\hline 0.72 & 22352217 & 18 \\
\hline 0.35 & 11046382 & 19 \\
\hline 0.2 & -122672010 & 20 \\
\hline 0.65 & 12266990 & 21 \\
\hline 0.65 & 99362210 & 22 \\
\hline 0.8 & 131400284 & 23 \\
\hline 0.7 & 99398793 & 24 \\
\hline 0.72 & 66105853 & 25 \\
\hline 0.22 & 16940157 & 26 \\
\hline
\end{tabular}

Source: Shpresa Çela

This is what we have explained through multiple regression.

The regression equation is: Factoring $=-33039+111.5$ Debt

Table 11. Regression analysis: Statistical indicators

\begin{tabular}{ccccc}
\hline Planned & Coefficients & $\begin{array}{c}\text { Standard } \\
\text { Error }\end{array}$ & Stat & P-value \\
\hline Intercept & 33.03943826 & 31.75254934 & -1.04053 & 0.308464 \\
\hline Debt tot/assets tot & 111.4995401 & 47.87672144 & 2.328888 & 0.028611 \\
\hline
\end{tabular}


Table 12. Regression statistics

\begin{tabular}{|c|c|c|}
\hline & Multiple R & 0.429338541 \\
\hline & R Square & 0.184331583 \\
\hline & Adjusted R Square & 0.150345398 \\
\hline & Standard Error & 59.90170741 \\
\hline & Observations & 26 \\
\hline
\end{tabular}

Table 13. Analysis of variance

\begin{tabular}{cccccc}
\hline Source & df & SS & MS & F & $\begin{array}{c}\text { Significance } \\
\text { F }\end{array}$ \\
\hline Regression & 1 & 19461.47486 & 19461.47 & 5.423721 & 0.028611 \\
\hline Residual & 24 & 86117.14921 & 3588.215 & & \\
\hline Total & 25 & 105578.6241 & & & \\
\hline
\end{tabular}

Value of probability $0.02<0.05$ shows the importance of debt at factoring.

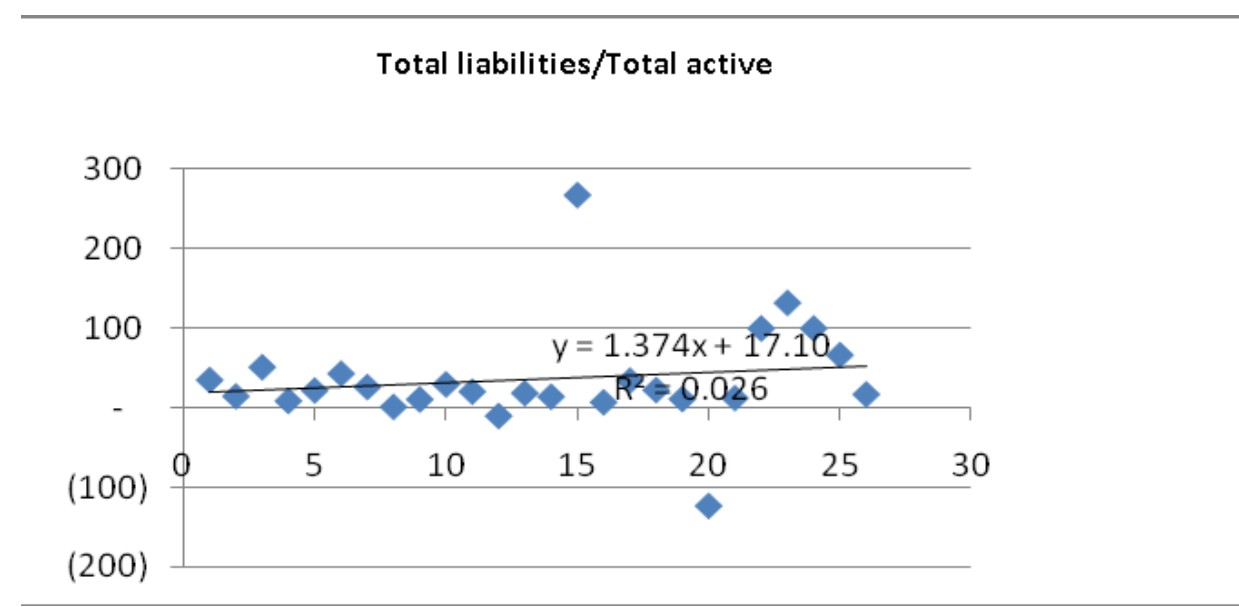

Figure 4. Relationship between debt and use of factoring

\section{So as shown in the graphic the usage of factoring is increased if the debt increases.}

Thus we have proved the above hypothesis.

\section{Conclusions}

- Number of SMEs significantly exceeds the number of factoring companies by creating a good environment for the development and expansion of the factoring industry.

- Financing through factoring is one of the tools that require less time and one of the easiest methods for providing liquidity for a company that has a positive result in the income statement.

- Factoring has an inverse relation with the level of debt to SMEs and availability of banks to lend, i.e. the higher the level of debt and the lower availability of banks to lend, the higher is the use of factoring.

- Albanian SMEs need liquidity and working capital and factoring will be a potential financial product available to the Albanian business. 
- A healthy cash flow is defined as a management tool in the company, this important indicator of liquidity has a negative correlation with factoring, so the lower the value of this indicator is, the more likely are companies to demand the use of financial factoring.

- Current ratio has a very important impact on the use of factoring, as the lower this indicator, the more SMEs are likely to use factoring as a source of financing for working capital.

\section{References}

Cfr. Mian e Smith (1992), Smith e Schnucker (1994), Summers e Wilson (2000) e Soufani (2001).

Daniel, J. Borgia, Ph.D., Deanna O. Burgess, Ph.D. Reducing the Cash Gap by Factoring, 2008.

Empirical Study by Shpresa Çela prill 2013

Factoring - Financing for Companies Seeking Fast Cash, Creative business planning Incorporated, 2010.

\section{Notes}

Note 1. Factoring - Financing for Companies Seeking Fast Cash, Creative business planning Incorporated.

Note 2. Daniel J. Borgia, Ph.D., Deanna O. Burgess, Ph.D. Reducing the Cash Gap by Factoring

Note 3. Empirical Study by Shpresa Çela prill 2013

Note 4. Cfr. Mian e Smith (1992), Smith e Schnucker (1994), Summers e Wilson (2000) e Soufani (2001). 